\title{
Addition of incretin therapy to metformin in type 2 diabetes
}

\author{
André J Scheen, Régis P Radermecker \\ University of Liège, Division of Diabetes, Nutrition and Metabolic Disorders and Clinical Pharmacology Unit, Department of Medicine, \\ CHU SartTilman, B-4000 Liège, Belgium
}

Incretin-based therapies offer a new approach for the management of type 2 diabetes, with a mechanism of action distinct from any existing class of glucose-lowering agents. ${ }^{1}$ These drugs improve the body's ability to control blood glucose by increasing active concentrations of glucagon-like peptide-1 (GLP-1). Two approaches have been used to enhance the action of GLP-1. First, incretin mimetics (exenatide) or analogues (liraglutide) act as agonists at the GLP-1 receptor to mimic the effect of endogenous GLP-1, but are resistant to degradation by dipeptidyl peptidase-4 (DPP-4). Second, drugs that specifically inhibit DPP-4 (sitagliptin, vildagliptin, saxagliptin) are used to increase the half-life of endogenous GLP-1 that is secreted in response to food intake. Both approaches have proven efficacy for reducing the concentration of glycosylated haemoglobin $\left(\mathrm{HbA}_{1 \mathrm{c}}\right)$, without inducing severe hypoglycaemic episodes or promoting weight gain. ${ }^{1}$ The drugs can be used alone or in combination with other oral glucose-lowering agents, such as metformin, sulphonylureas, andthiazolidinediones.

Almost all published randomised trials of incretin therapies compared the new compound with a placebo or a reference glucose-lowering agent, but head-to-head comparisons between two incretin-based therapies are scarce. Onetrial compared $1.8 \mathrm{mg}$ liraglutide once daily with $10 \mu \mathrm{g}$ exenatide twice daily, and showed greater efficacy and better tolerance with liraglutide. ${ }^{2} 2 \mathrm{mg}$ exenatide (longacting release) once weekly was more effective and bettertolerated than $10 \mu \mathrm{g}$ exenatide twice daily. ${ }^{3}$ No long-term comparisons of GLP-1 receptor agonists with DPP-4 inhibitors have been published, except in abstract form. ${ }^{4}$ Therefore evidence is lacking to clearly position GLP-1 receptor agonists versus DPP-4 inhibitors after failure to manage type 2 diabetes with metformin. ${ }^{5}$

Thus Richard Pratley and colleagues' 26-week, randomised, parallel-group, open-label trial, ${ }^{6}$ published in The Lancet today, is of great interest. Added to metformin, $1.2 \mathrm{mg}$ and $1.8 \mathrm{mg}$ liraglutide once daily significantly improved blood glucose control (change in $\mathrm{HbA}_{1 \mathrm{c}}$ from baseline: $-1.24 \%, 95 \% \mathrm{Cl}-1.37$ to -1.11 for $1.2 \mathrm{mg}$; $1.50 \%,-1.63$ to -1.37 for $1.8 \mathrm{mg})$ versus $100 \mathrm{mg}$ sitagliptin once daily $(-0.90 \%,-1.03$ to $-0.77 ; \mathrm{p}<0.0001$ for both comparisons). Furthermore, reductions in bodyweight were greater with $1.2 \mathrm{mg}$ and $1.8 \mathrm{mg}$ liraglutide $(-2.86 \mathrm{~kg}$, -3.39 to -2.32 for $1.2 \mathrm{mg} ;-3.38 \mathrm{~kg},-3.91$ to -2.84 for $1.8 \mathrm{mg})$ than with sitagliptin $(-0.96 \mathrm{~kg},-1.50$ to -0.42 ; $\mathrm{p}<0.0001$ for both comparisons). These results confirm previous reports of either liraglutide ${ }^{2,7}$ or sitagliptin $^{8-10}$ in patients with type 2 diabetes that was not well controlled with diet and metformin. Further, similar findings were recorded with exenatide twice daily, ${ }^{3,11}$ exenatide (longacting release) once weekly, ${ }^{2-4}$ and DPP-4 inhibitors vildagliptin $^{12}$ and saxagliptin ${ }^{13}$ (table).

Findings from today's study show the superiority of $1.8 \mathrm{mg}$ versus $1.2 \mathrm{mg}$ liraglutide for reduction of $\mathrm{HbA}_{1 \mathrm{c}}$, butthis result has not been recorded in previous studies (table). ${ }^{7}$ Only the $1.8 \mathrm{mg}$ dose of liraglutide was assessed in LEAD- $6,{ }^{2}$ in which liraglutide once daily was shown to be superior to $10 \mu \mathrm{g}$ exenatide twice daily for reduction of $\mathrm{HbA}_{1 \mathrm{c}}$. Therefore $1.2 \mathrm{mg}$ liraglutide should be considered as the starting dose in most patients with type 2 diabetes, with recommendations for titration up to $1.8 \mathrm{mg}$ if target $\mathrm{HbA}_{1 \mathrm{c}}$ concentrations are not reached. However, no study has been published in which patients who were insufficiently controlled on $1.2 \mathrm{mg}$ liraglutide had a significant improvement in glucose control from an increased dose of $1.8 \mathrm{mg}$ liraglutide.

The superiority of liraglutide versus sitagliptin for blood glucose control and weight reduction was probably due to increased circulating concentrations of the GLP-1 agonist, leading to different pharmacological effects, as shown with exenatide. ${ }^{14}$ Even though Pratley and colleagues recorded superior treatment satisfaction with $1.8 \mathrm{mg}$ liraglutide than with sitagliptin, the gastrointestinal tolerance profile is better with sitagliptin than with liraglutide, and one pill of sitagliptin daily might be judged as easier to administer than one subcutaneous injection of liraglutide daily. The increased cost of liraglutide should be compared with the benefit provided by improved glucose control and weight reduction. 
Table: Main randomised trials assessing efficacy of DPP-4 inhibitors or GLP-1 receptor agonists in patients with type 2 diabetes who had inadequate glycaemic control on metformin

\begin{tabular}{ccccc}
$\begin{array}{c}\text { Number of } \\
\text { patients }\end{array}$ & $\begin{array}{c}\text { Study duration } \\
\text { (weeks) }\end{array}$ & $\begin{array}{c}\text { Baseline } \\
\mathrm{HbA}_{\mathrm{lc}}\end{array}$ & $\begin{array}{c}\text { Reduction in } \\
\mathrm{HbA}_{\mathrm{lc}} *\end{array}$ & $\begin{array}{c}\text { Reduction in } \\
\text { bodyweight } \\
(\mathrm{kg})^{*}\end{array}$ \\
\hline
\end{tabular}

\section{DPP-4 inhibitors}

$100 \mathrm{mg}$ sitagliptin once daily

Charbonnel et al (2006) ${ }^{8}$

Scott et al $(2008)^{9}$

Nauck et al $(2007)^{10}$

Bergenstal et al (2009) ${ }^{4}$

Pratley et al $(2010)^{6}$

$50 \mathrm{mg}$ vildagliptin twice daily

Ferrannini et al (2009) $)^{12}$

$5 \mathrm{mg}$ saxagliptin once daily

De Fronzo et al (2009) $)^{13}$

\section{GLP-1 agonists}

$10 \mu \mathrm{g}$ exenatide twice daily

De Fronzo et al $(2005)^{11}$

Drucker et al $(2008)^{3 \dagger}$

464

94

588

166

219

1396

191

Buse et al (2009) 2 *

$2 \mathrm{mg}$ exenatide (longacting release)

once weekly

Drucker et al $(2008)^{3 \S}$

Bergenstal et al (2009) ${ }^{4}$

$1.2 \mathrm{mg}$ liraglutide once daily

Nauck et al (2009) ${ }^{7}$

Pratley et al (2010) ${ }^{6}$

$1.8 \mathrm{mg}$ liraglutide once daily

Nauck et al(2009)

Buse et al (2009) $)^{2}$

Pratley et al (2010) ${ }^{6}$

113

147

231

148

160

100

221

100

233

218
$7.96 \%$

$7.70 \%$

$7.40 \%$

$8.50 \%$

$8.5 \%$

$7.30 \%$

$8.10 \%$

$-0.68 \%$

$8.18 \%$

$-0.78 \%$

$-1.50 \%$

$-0.79 \%$

$8.20 \%$

$8.30 \%$

$-1.90 \%$

$-1.55 \%$

$-3.70$

$-2.70$

$-2.60$

$\begin{array}{ccc}8.30 \% & -1.10 \% & -2.60 \\ 8.4 \% & -1.24 \% & -2.86\end{array}$

26

$8.4 \%$

$-1.00 \%$

$-2.80$

$8.40 \%$

$-1.12 \%$

$-3.24$

26 $-1.50 \%$

* Result at end of follow-up (intention to treat, last observation carried forward) versus baseline. ${ }^{\dagger} 34 \%$ of patients on metformin alone. ${ }^{\ddagger} 27 \%$ of patients on metformin alone. ${ }^{\S} 38 \%$ of patients on metformin alone.

Some important information is still unknown, but could help clinicians to choose the best incretin therapy to manage type 2 diabetes after failure with metformin. We do not know how the efficacy of GLP-1 receptor agonists versus DPP-4 inhibitors will vary long term during the progressive decline in $\beta$-cell function that is responsible for loss of glucose control, and the development and progression of chronic diabetic complications. Long-term safety also remains an open question. In our opinion, the range of type 2 diabetes is so heterogeneous that treatment probably needs to be tailored to individuals ratherthan strictly standardised. ${ }^{5}$ Such an approach would need to take into consideration all biological, clinical, and psychosocial characteristics of every patient.

AJS and CHU Sart-Tilman have received fees for AJS's consulting on international advisory boards from SanofiAventis and AstraZeneca/Bristol-Myers Squibb, and on national advisory boards for AstraZeneca/Bristol-Myers Squibb, Eli Lilly, GlaxoSmithKline, Merck Sharp \& Dohme, Novo Nordisk, Sanofi-Aventis, and Novartis. AJS has received honoraria for participating in speakers' groups and expenses for travel and accommodation from AstraZeneca/Bristol-Myers Squibb, Eli Lilly, GlaxoSmithKline, Merck Sharp \& Dohme, Novo Nordisk, SanofiAventis, and Takeda. RPR has received honoraria for participating in speakers' groups from Novo Nordisk, Novartis, AstraZeneca, Bristol-Myers Squibb, Eli Lilly, GlaxoSmithKline, Merck Sharp \& Dohme, SanofiAventis, and Takeda; and has received expenses for travel and accommodation from Novo Nordisk, AstraZeneca/Bristol-Myers Squibb, Eli Lilly, GlaxoSmithKline, Merck Sharp \& Dohme, and Sanofi-Aventis. CHU SartTilman has a grant pending from Novo Nordisk, and has received fees for RPR's consulting on national advisory boards.

\section{References}

1 Drucker DJ, Nauck MA. The incretin system: glucagon-likepeptide-1 receptor agonists and dipeptidyl peptidase-4 inhibitors in type 2 diabetes. Lancet 2006; 368: 1696-705. 
2 Buse JB, Rosenstock J, Sesti G, et al, for the LEAD-6 Study Group. Liraglutide once a day versus exenatide twice a day for type 2 diabetes: a 26-week randomised, parallel-group, multinational, open-label trial (LEAD-6) Lancet 2009; 374: 39-47

3 Drucker DJ, BuseJB, Taylor K, et al, for the DURATION-1 Study Group. Exenatide once weekly versus twice daily for the treatment of type 2 diabetes: a randomised, open-label, non-inferiority study. Lancet 2008; 372: 1240-50.

4 Bergenstal R, Wysham C, Ping Y, Macconell L, Malloy J, Porter L. DURATION-2: exenatide once weekly demonstrated superior glycemic control and weight reduction compared to sitagliptin and pioglitazone after 26 weeks of treatment. 69th Scientific Sessions of the American Diabetes Association; New Orleans, LA, USA; June 5-9, 2009. Abstr 6-LB.

5 Nathan DM, Buse JB, Davidson MB, et al. Medical management of hyperglycaemia in type 2 diabetes: a consensus algorithm for the initiation and adjustment of therapy: a consensus statement from the American Diabetes Association and the European Association for the Study of Diabetes. Diabetologia 2009; 52: 17-30.

6 Pratley RE, Nauck M, Bailey T, et al, for the 1860-LIRA-DPP-4 Study Group. Liraglutide versus sitagliptin for patients with type 2 diabetes who did not have adequate glycaemic control with metformin: a 26-week, randomised, parallel-group, open-label trial. Lancet 2010; 375: $1447-56$.

7 Nauck M, Frid A, Hermansen K, et al, for the LEAD-2 Study Group. Efficacy and safety comparison of liraglutide, glimepiride, and placebo, all in combination with metformin, in type 2 diabetes: the LEAD (liraglutide effect and action in diabetes)-2 study. Diabetes Care 2009; 32: 84-90.

8 Charbonnel B, Karasik A, Liu J, Wu M, Meininger G, for the Sitagliptin Study 020 Group. Efficacy and safety of the dipeptidyl peptidase-4 inhibitor sitagliptin added to ongoing metformin therapy in patients with type 2 diabetes inadequately controlled with metformin alone. Diabetes Care 2006; 29: 2638-43.

9 Scott R, Loeys T, Davies MJ, Engel SS, for the Sitagliptin Study 801 Group. Efficacy and safety of sitagliptin when added to ongoing metformin therapy in patients with type 2 diabetes. Diabetes Obes Metab 2008; 10: 959-69.

10 Nauck MA, Meininger G, Sheng D,Terranella L, Stein PP, Sitagliptin Study 024 Group. Efficacy and safety of the dipeptidyl peptidase4 inhibitor, sitagliptin, compared with the sulfonylurea, glipizide, in patients with type 2 diabetes inadequately controlled on metformin alone: a randomized, double-blind, non-inferiority trial. Diabetes Obes Metab 2007; 9: 194-205.

11 De Fronzo RA, Ratner RE, Han J, Kim DD, Fineman MS, Baron AD. Effects of exenatide (exendin-4) on glycemic control and weight over 30 weeks in metformin-treated patients with type 2 diabetes. Diabetes Care 2005; 28: 1092-100.

12 Ferrannini E, Fonseca V, Zinman B, et al. Fifty-two-week efficacy and safety of vildagliptin vs. glimepiride in patients with type 2 diabetes mellitus

nadequately controlled on metformin monotherapy. Diabetes Obes Metab 2009; 11: 157-66.

13 DeFronzo RA, Hissa M, Garber AJ, et al, for the Saxagliptin 014 Study Group. The efficacy and safety of saxagliptin when added to metformin therapy in patients with inadequately control led type 2 diabetes on metformin alone. Diabetes Care 2009; 32: 1649-55.

14 DeFronzo RA, Okerson T, Viswanathan P, Guan X, Holcombe JH, MacConell L. Effects of exenatide versus sitagliptin on postprandial glucose, insulin and glucagon secretion, gastric emptying, and caloric intake: a randomized, cross-over study. Curr Med Res Opin 2008; 24: 2943-52. 